\title{
CORRESPONDENCE
}

\section{French nuclear cracks pose no danger}

SIR, - The article entitled "France faces a cold winter" (29 November, page 436), states that: "Although these cracks are not dangerous at this stage, Framatome experiments show that they tend to enlarge under the temperature transients of normal operating conditions, leading to possible component failure within four to six years, a failure which clearly would have catastrophic consequences involving the total loss of primary coolant."

And further that: "The only other possibility is permanent shutdown after five years" and: "These were the facts made public by both government and unions."

We regret that Nature did not consult the manufacturer of the components on which the cracks were found. The time limit of four to six years mentioned in your article (the currently accepted figure is six to eight years) concerns the minimum time for the cracks to fully penetrate the 10 to $16 \mathrm{~mm}$ thick stainless steel cladding which separates the reactor coolant from the component perse, and not the minimum time for component failure. Moreover this minimum time results from calculations based on the most pessimistic assumptions derived from experimental evidence. Similarly pessimistic calculations show that, after the cladding has been fully penetrated, component penetration could only occur several decades later. Furthermore, such penetration would result in a slow leak of primary coolant and in no way lead to what your article describes as "catastrophic consequences involving the total loss of primary coolant".

As concerns the last paragraph of the article, we have never been informed of any statements which contradict our position. Yours faithfully,

Framatome, Paris, France JACQUES GAUSSENS

\section{The technical experts must be heard}

SIR, - In your issue of 3 January (page 1) you had a short editorial entitled "Nuclear power: the critics must be heard". This seemed to me entirely sound but it is only half the story. Surely it is at least as important that the technical experts should be heard, and indeed listened to?

It is of course possible that the experts are biased, but it is also possible that critics are biased and while senior engineers might be unwilling to disclose all the relevant facts, you do not become a senior engineer by either ignorance of or misrepresentation of the technical facts of your profession and it is likely that the facts presented by such people are correct and worth listening to even if it is fair and reasonable for the critics to be exploring for facts which have not been released.

It must be apparent to anyone who has been watching the field that the media, especially the broadcasting media, frequently present as facts some quite wild guesses by critics and not infrequently fail to present facts given by the other side at all. A particularly serious example of this was a BBC programme towards the end of last year in which Dr Alice Stewart was given a sensible amount of time to discuss the reasons why she believes that doses of radiation are some 20 times as likely to produce cancer as is expected by the

International Commission for Radiological Protection.

In a long taped interview Dr Reissland of the National Radiological Protection Board gave a number of detailed reasons for believing that Dr Stewart's statistical analysis of cancer rates at Hanford, which supported her thesis, was unsound and that the experimental data were inadequate to contradict the much larger amount of evidence taken into account by the ICRP. These criticisms have not been effectively refuted, but they were not even presented. The only statement by Dr Reissland which appeared on the programme was his answer to a question by the comperre at the end of his interview asking him what would be the effect on radioactive regulations if Dr Stewart's findings were correct, to which Dr Reissland's answer was, when pressed, that if they had been correct it would involve a tightening up of regulations by a factor of 20 . Without giving his previous explanation of the reasons showing that her conclusions were not supportable, this gave a complete misrepresentation for which no apology has ever been made.

Yours faithfully, J. H. FREMLIN

Department of Physics, University of Birmingham, UK

\section{Civil liberties and the nuclear critics}

SIR, - Robin Grove White (20-27 December, page 774) has written a thoughtful and stimulating article on the alleged threat to civil liberties presented by an extended nuclear power programme. Unlike many (even most) critics of nuclear power, he is fair-minded enough to state that it is "conceivable" that alternative strategies would be worse. To his further credit, he takes seriously the possibility of "spying and infiltration of campaigning groups", even if he appears unsympathetic to the counter-measures available to the democracies.

However, I feel that it is unfair to intimate that there is anything peculiar to nuclear power about this latter aspect. The problem of uninvited involvement in our affairs seems to be with us anyway, as is indicated by such cases as those of Alger Hiss (according to a recent book), Philip Agee (according to a former CIA director) and Antony Blunt (according to himself). It is something which, in my opinion, the organisers of campaigns and demonstrations ought to face up to much more than they now do.

A problem to which $\mathrm{Mr}$ Grove White does not address himself at all is that of the tactics of some of the anti-nuclear people themselves. There have already been cases, in several countries, of vandalism and bombing. We can, I suppose, expect this behaviour to worsen if (as I expect and support) we choose to increase the contribution of nuclear power to the solution of our energy problems. At what point would these methods become an "impact ... on civil liberties"? If kidnappings start? Or assassinations? This is by no means a rhetorical question. To put it another way, at what stage can we expect civilised and decent critics of nuclear power to abandon their position because of the activities of some of their associates? Yours faithfully, J.F. CRAWFORD

Klein Doettingen, Switzerland

\section{Dioxin detection}

SIR, - With regard to Dr Warren Crummett's comments (24 January, page 330 ) on my report of Dow Chemical's poor performance in detecting TCDD (dioxin) (8 March 1979, page 109), I should like to make the following points.

- Dr Crummett was asked to comment on his results at the EPA meeting and he told me that they were "poor" and "worse" than normal.

- Most of Dr Crummett's criticism of my report refers to the detection of TCDD samples below 9 parts per trillion. He is of course correct to say that the collaborators concluded that $9 \mathrm{ppt}$ was the lowest acceptable detection limit and I made this point in my report.

- To my mind one of the most important issues is the reliability of measurements to detect TCDD in the 9-81 ppt range. Dow did not perform as well as the other laboratories in this study and the EPA report comparing all the results from the five laboratories bears testimony to this. Dr Crummett's comments to me at the EPA hearing only confirmed what was already in the EPA document. Yours faithfully,

University of Leeds, UK.

Alastair Hay

SIR, - My comments on Dr Hay's response are as follows:

I agree with Dr Hay that I used the words "poor" and "worse than normal", referring to the entire EPA Dioxin Implementation Plan study as "poor" and the Dow results in particular as "worse than normal".

The important issues in the reliability of the measurement of TCDD are, in order of importance: false positive results, false negative results, precision and accuracy of measurements, and confirmation by a second laboratory.

False positive results are most important because agencies in the United States, as explained by EPA's Tom Holloway at the Dioxin Implementation meeting, have a license to regulate whenever a toxic chemical is detected in environmental samples by state-ofthe-art analytical methodology. Dr Hay is correct, however, in stating that the reliability of measurements in the 9-81 ppt range is scientifically important. In this range Dow and Wright State University produced comparable results on the same samples. No other

laboratories examined identical extracts. So Dr Hay's comment that "Dow did not perform as well as the other laboratories" is his opinion.

I trust that this matter can now be put to rest without creating a continuous debate in your journal.

Dow Chemical, Michigan, US

WARREN B. CRUMMETT

\section{Suspicion of totalitarian ideologies}

SIR, - Vera Rich in the article "Berufsverbote continues in spite of resolutions"' 6

December, page 549) mentions the political disruption of academic life during the 1930s and remarks that it is strange that the antiBerufsverbot campaign started so late.

But it is the 1930s that have made us suspicious of any totalitarian ideology. Left and right terror is no different, and we have already had more than enough disruption by Marxists in our universities. We should not help them to occupy influential positions in government service unless we want the suicide of democracy. There is a German

proverb which says "Nur die allerdümmsten Kälber wählen ihre Schlächter selber"' (only foolish calves choose their own slaughterer). Yours faithfully,

Universitat Hamburg, West Germany 